\title{
Effect of Professional Ethics Auditor on Level of Materiality in Financial Statement Inspection
}

\author{
(Case Study of KAP in Padang City)
}

\author{
Wina Dewi Sakinah,Dewi Zulvia \\ Akuntansi, STIE"KBP” Padang \\ dewizulvia@aakbpstie.ac.id
}

\begin{abstract}
The purpose of this research are: Testing the influence of professionalism on the institutional level. This research uses simple linear regression analysis. The Reputable Variable in a professional auditor has a t count value of 0.000 with a significance level of $0.000<0.05$. This shows the existence. The results of this research also show the significance value of the $F$ test is 0.000 which has a value greater than 0.05. This means professionally affecting auditors simultaneously significant to levels. From result of determination test show matter - things that determine $\left(R_{2}\right)$ is equal to 0,714 , this mean $51 \%$ variable tax planing can be explained by perception variable of management accountant. While the rest $(100 \%$ $51 \%=49 \%)$, is given by other variables.
\end{abstract}

Keywords: Professional Ethics, Materiality

\section{PENDAHULUAN}

Financial Accounting Standart Board (FASB) menerangkan bahwa materialitas adalah : "Besarnya suatu penghilangan atau informasi salah saji akuntansi yang dilihat dari situasi yang menyeluruh serta memungkinkan pertimbangan yang dilakukan oleh seseorang yang menguasai pada informasi menjadi berubah atau dipengaruhi oleh penghilang atau salah saji tersebut".

PSAK No.25 dalam standart akuntan public dalam (SPAP:IAI,2001) yang menerangkan tentang "Resiko materialitas dan audit dalam pelaksanaan audit" menyatakan bahwa auditor harus mempertimbangkan materialitas dalam :Merencanakan audit dan menyusun prosedur audit, Mengevaluasikan laporan keuangan secara seluruhanya apakah disajikan secara wajar dalam semua hal-hal yang material, apakah sesuai dengan prinsip akuntansi yang berlaku umum. Contohnya terdapat pada "Kasus Enron" di Amerika Serikat yang berujung dibubarkannya kantor akuntan publik paling ternama di dunia. Arthur Andersen sudah menyurutkan kepercayaan masyarakat luas terhadap laporan keuangan 
perusahaan yang hanya menitik beratkan kemampuan pada perusahaan untuk mendapatkan laba saja, dan sama sekali tidak memperhatikan kepentingan sosial. Banyak terjadi masalah sosial dan dilingkungan tidak pernah terungkap dalam laporan keuangan perusahaan meskipun banyak dilaporkan terjadi masalah sosial dan lingkungan sebagai dampak negativ dari operasi suatu perusahaan publik. Banyak tuntutan untuk memasukkan biaya sosial dan lingkungan dalam laporan keuangan teraudit. Serta perilaku tidak etis yang sangat mengemukakan yaitu terjadinya manipulasi laporan keuangan untuk melihatkan seolah olah kinerja perusahaan terlihat baik. Dalam kasus Andersen diketahui terjadinya perilaku moral hazard seperti manipulasi laporan keuangan dengan terangkum keuntungan padahal perusahaan berdampak kerugian. Manipulasi dari keuntungan yang dikarenakan keinginan sebuah perusahaan supaya saham tetap diminati investor. Hal ini adalah salah satu contoh dari kasus pelanggaran etika profesi auditor yang terjadi di Negara Amerika Serikat, yaitu negara yang mempunyai segudang undang-undang bisnis dan pasar modal yang begitu lengkap. Contoh kasus lainnya, terdapat kasus keuangan dan manajerial perusahaan publik yang tidak bisa terdeteksi oleh akuntan publik yang menyebabkan perusahaan didenda oleh Bapepam yang empat diantaranya berhubungan dengan materialitas seperti terlihat pada tabel berikut ini :

Tabel 1.1

Kasus keuangan dan manajerial emiten yang pernah didenda Bapepem (Periode 2000-2002)

\begin{tabular}{|l|l|c|}
\hline \multicolumn{1}{|c|}{ Nama Emiten } & \multicolumn{1}{|c|}{ Jenis Pelanggaran } & Denda (Juta Rupiah) \\
\hline PT. Asuransi Ramayana & $\begin{array}{l}\text { Penyalahgunaan dana oleh } \\
\text { direksi }\end{array}$ & 11.197 \\
\hline PT. Asia Inti Selera & Pinjaman pda pihak istimewa & 358 \\
\hline PT. Myohdotcom & $\begin{array}{l}\text { Transaksi material dan } \\
\text { perubahan kegiatan usaha }\end{array}$ & \\
\hline
\end{tabular}

Tabel 1.2

\begin{tabular}{|l|l|c|}
\hline \multicolumn{1}{|c|}{ Nama Emiten } & \multicolumn{1}{|c|}{ Jenis Pelanggaran } & Denda (Juta Rupiah) \\
\hline PT. Bumi Resources & $\begin{array}{l}\text { Laporan atas transaksi } \\
\text { material }\end{array}$ & 100 \\
\hline PT. Semen Cibinong & $\begin{array}{l}\text { Deposito \$246,7 juta } \\
\text { dibank asing tidak jelas }\end{array}$ & \$250 \\
\hline $\begin{array}{l}\text { PT. Daya Guna } \\
\text { Samodra }\end{array}$ & $\begin{array}{l}\text { Menyembunyikan } \\
\text { informasi material }\end{array}$ & \\
\hline
\end{tabular}

Dalam pelaksanaan audit dilapangan, tingkat materialitas yang telah ditetapkan pada tahap pembuatan program pelaksaan dapat berubah seiring dengan adanya perubahan lingkup pemeriksaan. Jika seorang auditor tidak patuh terhadap kode etik akuntan, maka tingkat materialitas yang ditetapkan tidak akan 
sesuai dengan tujuan audit yang ingin dicapai. Penerapan kode etik akuntan ini membuat seorang auditor itu dapat bersikap professional sehingga kesalahan dalam audit dapat dikurangi (Binekas, 2013)

Menurut penelitian sebelumnya oleh (Binekas, 2013) yang meneliti tentang Pertimbangan auditor mengenai materialitas merupakan hasil dari proses pengambilan keputusan yang dilakukan berdasarkan etika profesional yang dimiliki dan menjadi modal kepercayaan dari masyarakat dan pengguna laporan audit bahwa seorang auditor itu bekerja sesuai dengan standar yang berlaku yang dilandasi dengan pelaksanaan kode etik. Hasil penelitian menunjukkan bahwa etika profesi berpengaruh positif terhadap tingkat materialitas. Dan penelitian sebelumnya yang dilakukan oleh (Muhammad, 2008) meneliti hubungan antara profesionalisme dengan pertimbangan materialitas pada auditor yang bekerja dikantor KAP Semarang. Penelitian dengan menggunakan dimensi profesi profesinalisme yang dikembangkan oleh Hall R (1698) menyimpulkan bahwa profesinalisme tersebut mempunyai hubungan kolerasi yag positif dengan pertimbangan materialitas.

Hal ini penting diteliti mengingat seorang auditor bisa saja tidak mengacu kepada etika profesinal dalam menentukan tingkat materialitas dalam proses pemeriksaan laporan keuangan. Penelitian ini akan menguji sejauhmana pengaruh etika profesional auditor terhadap tingkat materialitas dalam pemeriksaan laporan keuangan. Peneliti memilih untuk meneliti faktor tersebut karena etika profesi merupakan hal yang sangat penting dimiliki oleh seorang auditor guna mewujudkan laporan audit yang dapat dipercaya. Objek penelitian ini adalah Kantor Akuntan Publik di Kota Padang.

Berdasarkan teori dan latar belakang permasalahan yang telah dikemukakan sebelumnya, maka dapat dibuat beberapa jenis hipotesis terhadap permasalahan sebagai berikut :

Menurut penelitian sebelumnya oleh (Binekas, 2013) yang meneliti tentang Pertimbangan auditor mengenai materialitas merupakan hasil dari proses pengambilan keputusan yang dilakukan berdasarkan etika profesional yang dimiliki dan menjadi modal kepercayaan dari masyarakat dan pengguna laporan audit bahwa seorang auditor itu bekerja sesuai dengan standar yang berlaku yang dilandasi dengan pelaksanaan kode etik. Hasil penelitian menunjukkan bahwa etika profesi berpengaruh secara positif terhadap tingkat materialitas. Dan penelitian sebelumnya yang dilakukan oleh (Muhammad, 2008) meneliti hubungan antara profesionalisme dengan pertimbangan materialitas pada auditor yang bekerja dikantor KAP Semarang. Penelitian dengan menggunakan dimensi profesi profesinalisme yang dikembangkan oleh Hall R (1698) menyimpulkan bahwa profesinalisme tersebut mempunyai hubungan kolerasi yang positif dengan pertimbangan materialitas. 
$\mathrm{H}_{0} \quad$ : Etika profesional auditor berpengaruh tidak positif terhadap tingkat materialitas dalam pemeriksaan laporan keuangan.

$\mathrm{H}_{\mathrm{a}} \quad$ : Etika profesional auditor berpengaruh positif terhadap tingkat materialitas dalam pemeriksaan laporan keuangan.

\section{METODELOGI PENELITIAN}

Jenis penelitian ini menggunakan data penelitian kuantitatif. Penelitian kuantitatif yaitu jenis penelitian dimana proses pengkajian informasi dihasilkan berbentuk angka-angka dan melakukan analisis data dengan prosedur statistik, Indiantoro dan Supomo, 2014;23 dalam (Afsari, 2015) dengan menggunakan pendekatan korelasional. Pendekatan ini mempunyai arah, melihat apakah antara satu variabel atau lebih memiliki hubungan korelasi atau tidak. Dalam suatu teori, pendapat para ahli atau pun persepsi peneliti berdasarkan pada pengalamannya, lalu dikembangkan menjadi permasalahan-permasalahan dan diajukan guna untuk memperoleh pembuktian atau verifikasi dalam bentuk suatu dukungan berupa data empiris dilapangan. Bentuk penelitian kuantitatif penulis gunakan, untuk melihat bagaimanakah pengaruh variabel $\mathrm{X}$ terhadap variabel $\mathrm{Y}$. Dalam penelitian terdapat 2 variabel yaitu: a. Independen variabel (X) adalah Etika Profesional Auditor b. Dependen variabel (Y) adalah Tingkat Materialitas. Responden peneliti adalah pihak - pihak yang dijadikan sebagai sampel dalam sebuah penelitian. Unit analisis pada penelilian ini adalah akuntan publik. yaitu auditor senior dan junior yang ada pada Kantor Akuntan Publik (KAP) yang ada di Kota Padang, sebanyak 7 KAP.

Jenis data yang digunakan dalam penelitian ini yaitu jenis data interval. Data interval yaitu merupakan suatu data yang pengolahannya dilakukan dengan pemberian angka kepada set dari objek yang memiliki sifat-sifat ukuran ordinal yang ditambah dengan satu sifat lain, yaitu jarak yang sama pada pengukuran disebut data interval. Kelebihan data interval dibandingkan dengan data ordinal adalah memiliki suatu sifat kesaman jarak atau disebut juga dengan equality interval atau yang memiliki rentang sama antara data yang telah diurutkan. Untuk kegiatan penelitian ini data skor di dapat melalui kuesioner yaitu sebagai data interval setelah alternatif jawabannya diberikan skor yang ekuivalen atau setara dengan skala interval, misalnya Skor (5) untuk jawaban "Sangat Setuju", Skor (4) untuk jawaban "Setuju,Skor (3) untuk jawaban "Netral", Skor (2) untuk jawaban "Tidak Setuju", Skor (1) untuk jawaban "Sangat Tidak Setuju"

Sumber data yang dipakai dalam penelitian ini adalah data primer. Dimana data primer merupakan jenis data penelitian yang berbentuk opini, sikap, pengalaman atau karakteristik dari seseorang atau sekelompok orang yang menjadi subyek dalam penelitian ini atau responden Indriantoro dan Supomo, 2014:145 dalam (Afsari, 2015). Data primer ini berasal dari sumber asli atau pertama, data ini tidak tersedia dalam bentuk terkompilasi ataupun dalam bentuk file, data ini harus dicari melalui narasumber atau dalam istilah teknisnya 
responden, yaitu orang yang kita jadikan objek penelitian atau orang yang kita jadikan sebagai sarana mendapatkan informasi ataupun data (Sarwono, 2006). Tanggapan yang disampaikan oleh responden berupa respon tertulis melalui kuesioner yang telah diajukan oleh peneliti. Kuesioner yaitu daftar-daftar pernyataan yang memiliki hubungan dengan variabel yang akan diteliti yaitu karakteristik Etika Profesional Auditor dan Tingkat Materialitas.

Prinsip etika profesi dalam Kode Etik Akuntan Indonesia menyatakan pengakuan profesi akan tanggung jawab kepada publik dan pemakai jasa akuntan. Prinsip ini memandu anggota dalam memenuhi tanggung jawab terhadap profesionalismenya dan merupakan landasan dasar perilaku etika dan perilaku profesionalnya.(Dewi Zulvia, 2017)

Data yang dikumpulkan yaitu data yang didapat dari studi lapangan/survey langsung dari objek penelitian kuesioner kepada responden guna untuk mendapatkan informasi mengenai bagaimana pengaruh variabel $\mathrm{X}$ (Etika Profesional Auditor) terhadap variabel Y (Tingkat Materialitas).

Analisis data dalam penelitian ini menerapkan pendekatan kuantitatif dimana statistik merupakan alat analisis utamanya. Alat statistik yang digunakan di dalam penelitian yaitu regresi linier sederhana dengan bantuan software statistik SPSS. Statistik digunakan untuk menggambarkan suatu hubungan variabel (variabel independen) mempengaruhi variabel lainnya (variabel dependen) dan meringkas hal-hal penting dari data antara lain berupa nilai maksimum dan minimum, standar deviasi, frekuensi, penyebaran dan pemusatan data. Apriyadi, 2013 dalam (Afsari, 2015), menjelaskan bahwa statistik deskriptif digunakan untuk mendeskripsikan data yang telah diperoleh untuk masing-masing variabel penelitian tanpa bermaksud membuat kesimpulan yang berlaku umum.

Uji Kualitas data dalam pengukuran dan pengujian ini, dilakukan berdasarkan pada data kuesioner yang telah kita dapat setelah penyebaran kuesioner tersebut. Data merupakan gambaran suatu objek atau variabel yang akan diteliti dan juga memegang peranan penting dalam suatu penelitian, sebelum data diolah instrumen ini diuji terlebih dahulu dengan menggunakan uji validitas dan reliabilitas agar memperoleh hasil yang bisa dipertanggung jawabkan. Uji validitas adalah suatu ukuran yang memperlihatkan tingkat kevalidan atau keaslian suatu instrument, suatu instrument dikatakan valid jika memiliki validitas tinggi. Sebaliknya instrument dikatakan kurang valid berarti memiliki validitas rendah. Kuesioner dikatakan valid jika pernyataan pada kuesioner mampu untuk mengungkapkan sesuatu yang akan diukur oleh kuesioner tersebut, Ghozali, 2016:52 dalam (Kusuma, 2013). Menurut (Johan, 2017) uji validitas ini mengunakan KMO and Bartlett's Test. Dimana nilai Kaiser-mayer-olkin test berkisar dari 0-1, semakin mendekati 1, berarti semakin bagus dan nilai yang dapat di terima adalah diatas 0,5. Nilai Bartlett's test yang dapat di terima adalah jika signifikansi dibawah 0,05 dan sangat bagus jika dibawah 0,01. Uji reliabilitas adalah merupakan alat pengukuran suatu kuesioner 
yang merupakan indikator dari variabel atau kontruk. Suatu kuesioner dibilang reliabel atau handal adalah jika jawaban seseorang terhadap pernyataan adalah konsisten atau stabil dari waktu ke waktu Ghozali, 2016:47 dalam (Afsari, 2015). Menurut (Johan, 2017) Teknik yang dipakai menguji reliabilitas yaitu menggunakan Cronbach Alpha. Kriteria pengujian ini adalah jika koefisien alpha (a) > 0,6 maka instrumen yang digunakan dikatakan reliable. Setelah data dideskripsikan dalam uji kualitas data, langkah selanjutnya adalah melakukan uji asumsi klasik. Pengujian asumsi klasik meliputi beberapa pengujian, antara lain: Uji Normalitas: Pengujian normalitas memiliki tujuan untuk mengetahui apakah dalam sebuah model regresi, error yang dihasilkan mempunyai retribusi atau tidak. Model regresi yang baik adalah model regresi yang memiliki distribusi data normal atau mendekati normal (Afsari, 2015). Pengujian ini dilakukan melalui 2 cara: Histogram :Pengujian dengan menggunakan histogram akan menunjukkan data terdistribusi normal apabila diagram histogram mengikuti pola garis yang berbentuk lonceng. Sebaliknya apabila diagram histogram tidak mengikuti pola garis berbentuk lonceng maka bisa disimpulkan data tidak terdistribusi normal. Kolmogorov Smirnov: Pengujian dengan ini akan menunjukkan bahwa data terdistribusi normal ketika nilai sig > 0,05 dan sebaliknya ketika nilai sig $<0,05$ maka disimpulkan bahwa data tidak terdistribusi normal. Uji homogenitas bertujuan untuk melihat sama tidaknya variansi-variansi dua buah distribusi atau lebih. Uji homogenitas dilakukan untuk mengetahui apakah data variabel $\mathrm{X}$ dan variabel $\mathrm{Y}$ bersifat homogen, apabila nilai signifikansinya besar dari 0,05. Analisis regresi linier sederhana adalah hubungan secara linear antara satu variable independen $(X)$ dengan variable dependen (Y). Anaalisis ini untuk mengetahui arah hubungan antara variable independen dengan variable dependen apakah pisitif atau negative dan untuk memprediksi nilai dari variiabel dependen apabila nilai variable independen mengalami kenaikan atau penurunan. Setelah melakukan uji asumsi klasik dan dinyatakan lulus maka tahap berikutnya yaitu melaksanakan uji atas hipotesis, hasil pengujian atas hipotesis, digunakan sebagai dasar pengambilan keputusan terkait dengan hubungan antara variabel dependen dan independen. Terdapat 3 pengujian pada tahapan ini yaitu: Uji $\mathrm{F}$ : Pengujian ini bertujuan untuk mengetahui apakah variabel independen secara simultan berpengaruh terhadap variabel dependen. Significance level yang dipakai adalah 0,05, apabila significance level > 0,05 maka $\mathrm{H}_{0}$ diterima (variabel independen secara bersama-sama tidak berpengaruh secara simultan terhadap variabel dependen). Sebaliknya jika significance level $<0,05$ maka $\mathrm{H}_{0}$ ditolak (maka secara bersamasama dapat diartikan bahwa variabel independen berpengaruh simultan terhadap variabel dependen). Uji T : Pengujian ini bertujuan untuk mengetahui apakah variabel independen secara parsial berpengaruh terhadap variabel dependen. Menggunakan significance level 0,05. Jika significance level berada diatas 0,05 maka $\mathrm{H}_{0}$ diterima atau dapat diartikan bahwa variabel independen tidak 
berpengaruh secara parsial terhadap variabel dependen. Sebaliknya ketika significance level berada dibawah 0,05 maka $\mathrm{H}_{0}$ ditolak, dapat disimpulkan bahwa variabel independen berpengaruh secara parsial terhadap variabel dependen. Uji Koefisien Determinasi $\left(\mathrm{R}^{2}\right)$ : Pengujian bertujuan untuk mengetahui seberapa besar (persentase) variasi variabel $\mathrm{X}$ berpengaruh terhadap variabel Y. Nilai koefisiensi determinasi ini di antara 0 dan $1\left(0<\mathrm{R}^{2}<1\right)$. Semakin tinggi nilai $\mathrm{R}^{2}$ dari model regresi maka hasil regresi semakin baik. Nilai $\mathrm{R}^{2}$ mendekati 1 berarti variabel-variabel independen memberikan hampir seluruh informasi yang dibutuhkan untuk memprediksi variasi variabel dependen Ghozali, 2005:83 dalam (Afsari, 2015). Kelemahan mendasar dari pengguna koefisien determinasi adalah terhadap bias jumlah variabel independen. Setiap 1 variabel independen bertambah dapat meningkatkan nilai $\mathrm{R}^{2}$, tidak peduli apakah variabel tersebut berpengaruh signifikan terhadap variabel dependen. Oleh karena itu, dalam penelitian ini tidak lagi menggunakan koefisien determinasi $\left(\mathrm{R}^{2}\right)$ namun menggunakan koefisien determinasi yang disesuaikan (adjustes $\mathrm{R}^{2}$ ), karena adjusted $\mathrm{R}^{2}$ dapat, apabila 1 variabel independen naik atau turun ditambahkan kedalam model lain.

\section{HASIL DA PEMBAHASAN}

\section{Hasil uji KMO and Bartlett's Test}

\begin{tabular}{|c|c|c|c|}
\hline Variabel & $\begin{array}{c}\text { Batasan } \\
\text { Nilai }\end{array}$ & $\begin{array}{c}\text { KMO and } \\
\text { Bartletts's }\end{array}$ & Keputusan \\
\hline Variabel X & 0,50 & 0.805 & Valid \\
\hline Variabel Y & 0,50 & 0.861 & Valid \\
\hline
\end{tabular}

Sumber: Data Primer diolah dengan SPSS 23 (2018)

Berdasarkan tabel 4.8 tingkat konsistensi dan akurasi menunjukkan cukup baik. Berdasarkan hasil perhitungan yang ditunjukkan pada tabel diatas nilai Kaiser-Meyer-Olkin Measure Of Sampling Adequacy (Kaiser's MSA) sebesar 0.805> 0,50 sehingga dapat disimpulkan bahwa butir-butir pernyataan pada variabel $\mathrm{X}$ dinyatakan valid dan pada variabel $\mathrm{Y}$, nilai Kaiser-Meyer-Olkin Measure Of Sampling Adequacy (Kaiser's MSA) sebesar 0,861>0,50 dan dapat disimpulkan juga bahwa butir-butir pernyataan pada variabel $\mathrm{Y}$ dinyatakan valid.

Hasil Uji Reliabilitas

\begin{tabular}{|l|c|c|c|}
\hline Variabel & $\begin{array}{c}\text { Batasan } \\
\text { Nilai }\end{array}$ & $\begin{array}{c}\text { Cronbach's } \\
\text { Alpha }\end{array}$ & Keputusan \\
\hline Etika Profesionalisme & 0,60 & 0,877 & Reliabel \\
\hline
\end{tabular}




\begin{tabular}{|l|c|c|c|}
\hline Auditor (X) & & \\
\hline $\begin{array}{l}\text { Tingkat materialitas } \\
\text { Dalam Laporan } \\
\text { Keuangan (Y) }\end{array}$ & 0,60 & 0,932 & Reliabel \\
\hline
\end{tabular}

Sumber: Data Primer diolah dengan SPSS 23 (2018)

Berdasarkan pada tabel 4.9 di atas, hasil pengujian menemukan untuk seluruh variabel mempunyai cronbach's Alpha yang cukup besar yaitu berada di atas 0,60, sehingga dapat dikatakan semua konsep pengukuran masing-masing variabel dari kuesioner adalah reliabel sehingga selanjutnya item-item pada masing-masing variabel tersebut dapat digunakan sebagai alat ukur lebih lanjut.

\section{Hasil Uji Normalitas}

One-Sample Kolmogorov-Smirnov Test

\begin{tabular}{|c|c|c|c|}
\hline Variabel & Batasan Nilai & $\begin{array}{c}\text { Asymp. Sig } \\
\text { (2-tailed) }\end{array}$ & Keputusan \\
\hline $\begin{array}{lr}\text { Etika } & \text { Profesional } \\
\text { Auditor } & (\mathrm{X}) \text { dan } \\
\text { Tingkat } & \text { materialitas } \\
\text { dalam } & \text { Pemeriksaan } \\
\text { Laporan } & \text { Keuangan } \\
\text { (Y) } & \end{array}$ & 0,05 & 0.2 & $\begin{array}{c}\text { Terdistribusi } \\
\text { Normal }\end{array}$ \\
\hline
\end{tabular}

Sumber: Data Primer diolah dengan SPSS 23 (2018)

Hasil uji normalitas dengan menggunakan uji Kolmogorov-Smirnov dilihat dari nilai signifikan dari data yang telah diolah. Berdasarkan tabel diatas, dapat dilihat bahwa besarnya nilai Kolmogorov-Smirnov Test menghasilkan Asympotic Significance lebih besar dari 0,05 yaitu 0.2 >0,05. Berdasarkan hasil uji ini dapat disimpulkan bahwa model regresi telah memenuhi asumsi kenormalan. 


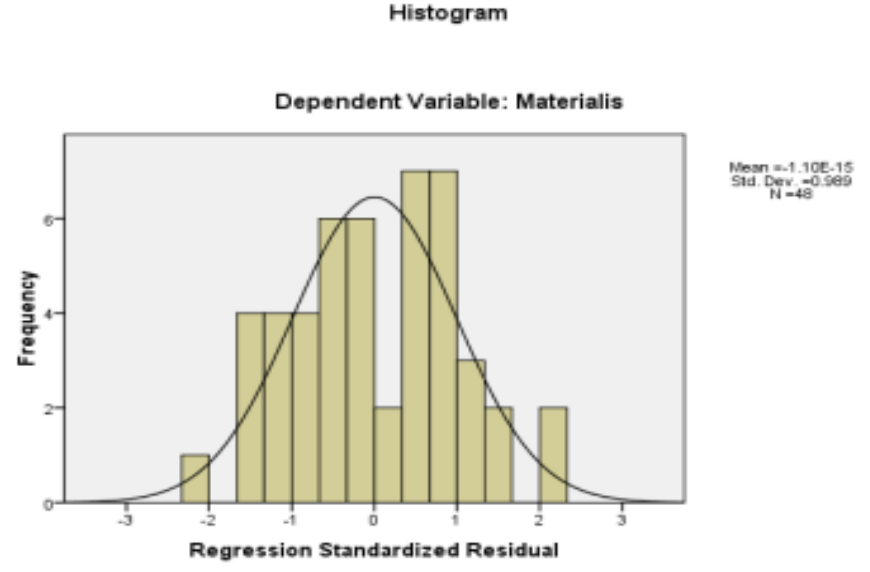

Normal P-P Plot of Regression Standardized Residual

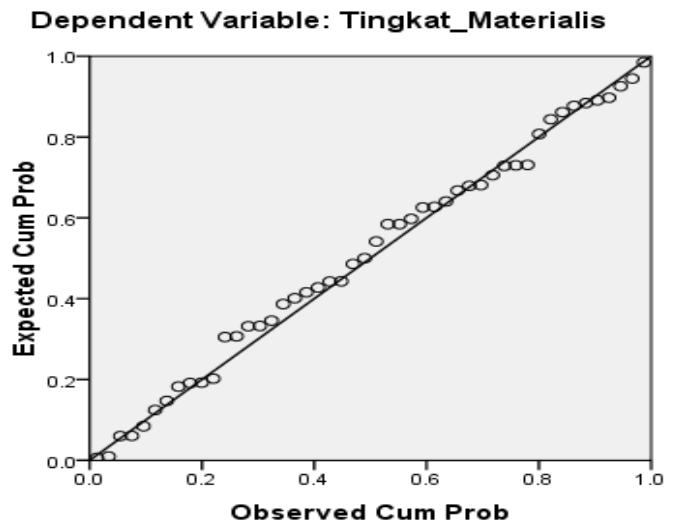

Pada gambar menunjukkan adanya titik-titik data yang tersebar di sekitar garis diagonal. Hal ini berarti model regresi dalam penelitian ini memenuhi asumsi normalitas berdasarkan grafik normal probability plot dan mengikuti pola garis yang berbentuk lonceng pada diagram histogram. Dengan demikian berdasarkan gambar diagram histogram dan grafik probability plot bahwa model fit atau baik dan dapat dinyatakan bahwa distribusi data residual normal.

Hasil Uji Homogenitas

\begin{tabular}{|c|c|c|c|}
\hline Variabel & Batasan Nilai & Homogenitas & Keputusan \\
\hline $\begin{array}{c}\text { Variabel X } \\
\text { dan Y }\end{array}$ & 0,05 & 0.132 & $\begin{array}{c}\text { Bersifat } \\
\text { Homogenitas }\end{array}$ \\
\hline
\end{tabular}

Sumber: Data Primer diolah dengan SPSS 23 (2018) 
Berdasarkan pada tabel di atas, hasil pengujian uji homogenitas memperoleh hasil 0.132. Dimana data dikatakan homo apabila nilai signifikannya besar dari 0,05. Hasil untuk data penelitian ini adalah $0.132>0,05$ maka dapat dikatakan varian dari dua kelompok sampel data yaitu Etika Profesionalisme Auditor terhadap Tingkat materialitas Dalam Laporan Keuangan adalah sama atau bersifat homogenitas, maka hal ini telah memenuhi asumsi dasar.

Hasil Analisis Regresi Linier Sederhana

\begin{tabular}{|l|c|}
\hline \multicolumn{1}{|c|}{ Variabel } & Koefisien Regresi \\
\hline Konstanta & 16.777 \\
\hline Etika Profesional Auditor (X) & 0,656 \\
\hline
\end{tabular}

Sumber: Data Primer diolah dengan SPSS 23 (2018)

Berdasarkan tabel diatas, dapat dilihat bahwa:

$\mathrm{a}=16.777$ (Konstanta)

$\mathrm{b}=0,656$ (Koefisien pada hasil)

Sehingga diperoleh model estimasi persamaan regresi sederhana adalah sebagai berikut:

Dimana:

$$
\begin{aligned}
& Y=a+b X+e \\
& Y=16.777+0,656 x+e
\end{aligned}
$$

$\mathrm{Y}=$ Tingkat materialitas dalam Pemeriksaan Laporan Keuangan

$\mathrm{X}=$ Etika Profesional Auditor

Dari persamaan diatas, dapat dijelaskan bahwa:

a. Konstanta memiliki nilai sebesar 16.777 mengidentifikasikan variabel $\mathrm{Y}$ yaitu Tingkat materialitas dalam Pemeriksaan Laporan Keuangan. Jika variabel X yaitu Etika Profesional Auditor bernilai nol (0), maka nilai Tingkat materialitas dalam Pemeriksaan Laporan Keuangan adalah sebesar nilai konstanta yaitu 16.777

b. Nilai koefisien regresi Etika Profesional Auditor sebesar 0,656 mengidentifikasikan bahwa setiap peningkatan Etika Profesional Auditor satu satuan akan mengakibatkan peningkatan Tingkat materialitas dalam Pemeriksaan Laporan Keuangan sebesar 0,656 satuan. Hal ini mengindikasikan bahwa nilai Etika Profesional Auditor berpengaruh positif terhadap Tingkat materialitas dalam Pemeriksaan Laporan Keuangan. Dengan demikian dapat diartikan bahwa semakin baik Etika Profesional Auditor yang diterapkan maka semakin baik juga terhadap Tingkat materialitas dalam Pemeriksaan Laporan Keuangan pada seluruh Kantor Akuntan di Kota Padang.

Koefisien regresi Etika Profesional Auditor bernilai positif. Berarti ada pengaruh positif antara Etika Profesionalisme Auditor terhadap Tingkat 
materialitas dalam Pemeriksaan Laporan Keuangan. Maksudnya semakin baik Etika Profesional Auditor yang diterapkan oleh setiap Kantor Akuntan Publik maka semakin baik juga Tingkat materialitas dalam Pemeriksaan Laporan Keuangan yang ada diseluruh Kantor Akuntan Publik di Kota Padang

\section{Hasil Uji F}

ANOVA $^{b}$

\begin{tabular}{|l|r|r|r|r|r|}
\hline Model & $\begin{array}{c}\text { Sum of } \\
\text { Squares }\end{array}$ & df & Mean Square & F & Sig. \\
\hline Regression & 430.110 & 1 & 430.110 & 47.890 & $.000^{\mathrm{a}}$ \\
Residual & 413.140 & 46 & 8.891 & & \\
Total & 843.250 & 47 & & & \\
\hline
\end{tabular}
a. Predictors:
(Constant), Etika
b. Dependent Variable: Materialis

Berdasarkan tabel diatas dapat dilihat bahwa dalam pengujian regresi sederhana menunjukkan hasil $F$ hitung sebesar 47,890 dengan tingkat signifikannya 0,000 yang lebih kecil dari dari 0,05 , dari hasil signifikan ini dapat dikatakan bahwa $\mathrm{H}_{0}$ ditolak dan $\mathrm{H}_{\mathrm{a}}$ diterima, maka variabel independen secara bersama-sama berpengaruh signifikan terhadap variabel dependent atau dapat dikatakan bahwa Etika Profesional Auditor (X) berpengaruh terhadap Tingkat materialitas dalam Pemeriksaan Laporan Keuangan (Y).

\section{Hasil Uji T \\ Coefficients $^{\mathrm{a}}$}

\begin{tabular}{|l|r|r|r|r|r|}
\hline & \multicolumn{2}{|c|}{$\begin{array}{c}\text { Unstandardized } \\
\text { Coefficients }\end{array}$} & $\begin{array}{c}\text { Standardized } \\
\text { Coefficients }\end{array}$ & & \multirow{2}{*}{ Sig. } \\
\cline { 2 - 5 } Model & \multicolumn{1}{|c|}{$\mathrm{B}$} & Std. Error & \multicolumn{1}{c|}{ Beta } & \multicolumn{1}{c|}{$\mathbf{t}$} & \multicolumn{1}{c|}{ S } \\
\hline (Constant) & 16.777 & 3.652 & & 4.593 & .000 \\
Etika & .656 & .095 & .714 & 6.920 & .000 \\
\hline
\end{tabular}

a. Dependent Variable: Materialis

Sumber: Data Primer diolah dengan SPSS 23 (2018)

Berdasarkan atas hasil pengujian yang terdapat dalam tabel 4.14 menghasilkan nilat $\mathrm{t}$ dan sig untuk variabel independen yang akan digunakan dalam pengambilan keputusan dalam uji $\mathrm{T}$ ini. Uji $\mathrm{T}$ yang dilakukan dalam penelitian ini dengan melihat nilai signifikannya kemudian dibandingkan dengan tingkat signifikan sebesar 0.000. Jika sig lebih besar dari tingkat signifikan maka $\mathrm{H}_{0}$ akan diterima tapi jika nilai signifikan lebih kecil maka $\mathrm{H}_{0}$ ditolak. Hipotesis yang akan diteliti, dimana peneliti akan menguji apakah variabel Etika 
Profesionalisme Auditor akan mempengaruhi Tingkat materialitas Dalam Laporan Keuangan .

Hipotesis:

$\mathrm{H}_{0}$ : Etika profesional auditor berpengaruh tidak positif terhadap tingkat materialitas dalam pemeriksaan laporan keuangan.

$\mathrm{H}_{\mathrm{a}}$ : Etika profesional auditor berpengaruh positif terhadap tingkat materialitas dalam pemeriksaan laporan keuangan.

Dari hasil nilai sig sebesar 0,000 yang berarti lebih kecil dibandingkan dengan tingkat signifikansi sebesar 0,05 yaitu $0,000<0,05$. Maka dapat disimpulkan bahwa $\mathrm{h}_{0}$ ditolak dan $\mathrm{h}_{\mathrm{a}}$ diterima yang menunjukkan bahwa Etika Profesional $\mathrm{n}$ Auditor merupakan faktor yang mempengaruhi Tingkat materialitas Dalam Laporan Keuangan .

\section{Hasil Uji Koefisien Determinasi $\left(\mathbf{R}^{2}\right)$}

\begin{tabular}{|l|r|r|r|r|}
\hline Model & \multicolumn{1}{|c|}{ R } & R Square & $\begin{array}{c}\text { Adjusted R } \\
\text { Square }\end{array}$ & $\begin{array}{l}\text { Std. Error of } \\
\text { the Estimate }\end{array}$ \\
\hline 1 & $.714^{\mathrm{a}}$ & .510 & .499 & 2.99688 \\
\hline
\end{tabular}

a. Predictors: (Constant), Etika

b. Dependent Variable: Materialis

Sumber: Data Primer diolah dengan SPSS 23 (2018)

Berdasarkan hasil uji koefisien determinasi diatas, nilai $\mathrm{R}^{2}$ (Adjusted $R$ Square) dari model regresi digunakan untuk mengetahui seberapa besar kemampuan variabel bebas (independen) dalam menerangkan variabel terikat (dependen). Dari tabel diatas diketahui bahwa nilai $\mathrm{R}^{2}$ sebesar 0,510 , hal ini berarti bahwa 51\% menunjukkan bahwa Etika Profesional dipengaruhi oleh Tingkat Materialitas. Sisanya sebesar $49 \%$ dipengaruhi oleh variabel lainnya yang tidak dimasukkan kedalam model regresi dalam penelitian ini. Dapat disimpulkan bahwa Etika Profesionalisme Auditor berpengaruh sebesar 51\% terhadap Tingkat materialitas Dalam Laporan Keuangan, sedangkan sisanya sebesar 49\% dipengaruhi oleh variabel lain yang tidak diteliti

Berdasarkan atas hasil pengujian nilat $t$ dan sig untuk variabel independen yang akan digunakan dalam pengambilan keputusan dalam uji $\mathrm{T}$ ini. Uji $\mathrm{T}$ yang dilakukan dalam penelitian ini dengan melihat nilai signifikannya kemudian dibandingkan dengan tingkat signifikan sebesar 0.000. Jika sig lebih besar dari tingkat signifikan maka $\mathrm{H}_{0}$ akan diterima tapi jika nilai signifikan lebih kecil maka $\mathrm{H}_{0}$ ditolak. Dari hasil nilai sig sebesar 0,000 yang berarti lebih kecil dibandingkan dengan tingkat signifikansi sebesar 0,05 yaitu $0,000<0,05$. Maka dapat disimpulkan bahwa $\mathrm{h}_{0}$ ditolak dan $\mathrm{h}_{\mathrm{a}}$ diterima yang menunjukkan bahwa Etika Profesional Auditor merupakan faktor yang mempengaruhi Tingkat materialitas Dalam Laporan Keuangan 


\section{KESIMPULAN DAN SARAN}

Berdasarkan hasil uji-uji yang diuraikan dalam pembahasan, maka penulis mengambil beberapa kesimpulan yaitu : Berdasarkan uji hipotesis secara parsial (uji t) menunjukkan bahwa variabel Etika Profesional berpengaruh terhadap Tingkat Materialitas dalam Pemeriksaan Laporan Keuangan. Hal ini dikarenakan nilai signifikansi $(0.000)<0.05$. maka hipotesis diterima.

Berdasarkan hasil penelitian, saran-saran yang dapat diberikan oleh penulis adalah sebagai berikut :

1. Kantor Akuntan Publik disarankan untuk mengharuskan pada auditor yang bekerja didalam KAP untuk melaksanakan etika audit dengan tepat, hal tersebut tentu sangat penting sebagai upaya untuk mengurangi tingkat materialitas dalam laporan keuangan.

2. Auditor disarankan untuk melaksanakan kegiatan audit sesuai dengan etika dan nilai profesionalisme yang tinggi agar ketepatan dan akurasi proses audit dapat terus ditingkatkan dan bermanfaat positif bagi perusahaan klient.

3. Peneliti dimasa mendatang disarankan untuk mencoba memperbanyak jumalah responden peneliti serta menambah variable baru yang belum digunakan dalam penelitian. 


\section{UCAPAN TERIMA KASIH}

Dengan terselesaikannya penelitian ini, penulis ingin mengucapkan terima kasih kepada pihak-pihak yang turut membantu hingga penelitian ini terselesaikan. Dengan kerendahan hati dan rasa terima kasih saya kepada :

1. Tuhan Yang Maha Esa yang telah memberikan kesempatan untuk menyelesaikan penelitian ini.

2. Bapak Febryandhie Ananda, SE, M.Si Selaku Ketua STIE "KBP”, dan Pembimbing Akademik serta sebagai Penguji Satu

3. Ibu Lidya Marta, SE, MM Selaku Wakil Ketua STIE "KBP”

4. Ibu Dewi Zulvia SE, MM Selaku Ketua Program Studi dan Dosen Pembimbing Skripsi

5. Ibu Lisa Amelia Herman SE, M.Si Selau Penguji Dua

6. Bapak dan Ibu yang berkerja di KAP Armanda \& Enita yang telah bersedia meluangkan waktu untuk mengisi kuesioner

7. Bapak dan Ibu yang berkerja di KAP Ekamasni, Bustaman \& Rekan yang telah bersedia meluangkan waktu untuk mengisi kuesioner

8. Bapak dan Ibu yang berkerja di KAP Drs. Gafar Salim \& Rekan yang telah bersedia meluangkan waktu untuk mengisi kuesioner

9. Bapak dan Ibu yang berkerja di KAP Indra Suheri \& Rekan yang telah bersedia meluangkan waktu untuk mengisi kuesioner

10. Bapak dan Ibu yang berkerja di KAP Drs. Rinaldi Munaf yang telah bersedia meluangkan waktu untuk mengisi kuesioner

11. Bapak dan Ibu yang berkerja di KAP Priza,Adi,Syaril \& Rekan yang telah bersedia meluangkan waktu untuk mengisi kuesioner

12. Bapak dan Ibu yang berkerja di KAP Drs. Sayuti Gazali yang telah bersedia meluangkan waktu untuk mengisi kuesioner 


\section{DAFTAR PUSTAKA}

Afsari, S. F. (2015). Analisis Faktor - Faktor Yang Mempengaruhi Kecenderungan Kecurangan (Fraud) di Sektor Pemerintahan Berdasarkan Teori Fraud Triangle, 115.

Binekas, B. (2013). Pengaruh Etika Profesional Auditor terhadap Pertimbangan Tingkat Materialitas dalam Pemeriksaan Laporan Keuangan.

Dewi Zulvia, N. sari dan R. S. (2017). Persepsi Akuntan Publik Dan Mahasiswa Akuntansi Terhadap kode Eti Profesi Akuntan Pada Kantor Akuntan Publik Dan Mahasiswa Akuntansi. Jurnal Pundi, 01(03), 213-222.

Johan, A. P. (2017). Pelatihan Statistik Versi 23. Universitas Andalas.

Kusuma, M. I. Y. (2013). Analisis Faktor-Faktor Yang Mempengaruhi Tingkat Penerapan Akuntansi Akrual Pada Pemerintah. Ekonomika Dan Bisnis, 1-54.

Muhammad, R. (2008). Analisis Hubungan Antara Profesionalisme Auditor dengan Pertimbangan Tingkat Materialitas dalam Proses Pengauditan Laporan Keuangan. Jurnal Fenomena, 1-13.

Sarwono, J. (2006). Analisis Data Penelitian Menggunakan SPSS. Yogyakarta: CV Andi Offset. 